\title{
Effect of lignocaine, sodium cromoglycate, and ipratropium bromide in exercise-induced asthma
}

\author{
WM TUlLETT, KR PATEL, KE BERKIN, JW KERR \\ From the Department of Respiratory Medicine, Western Infirmary, Glasgow
}

ABSTRACT Eight patients with exercise-induced asthma participated in a single-blind trial comparing the protective effects of inhaled lignocaine (estimated dose $48 \mathrm{mg}$ ), sodium cromoglycate (estimated dose $12 \mathrm{mg}$ ), and ipratropium bromide (estimated dose $120 \mu \mathrm{g}$ ). Saline was used as control. Effects were assessed from the mean maximal percentage fall in forced expiratory volume in one second $\left(F E V_{1}\right)$ and maximal mid-expiratory flow rates (MMFR) after they had run on a treadmill for eight minutes. There was no significant change in baseline FEV 1 or MMFR before each agent was given. Saline, lignocaine, and sodium cromoglycate did not alter the mean baseline $\mathrm{FEV}_{\mathrm{l}}$ or MMFR significantly. Ipratropium caused bronchodilatation with an increase of $16.3 \%$ in the mean FEV $1(p<0.001)$ and of $43.4 \%$ in the mean MMFR $(p<0.05)$. After exercise the maximal percentage falls in $\mathrm{FEV}_{1}$ (means and SEM) after saline, lignocaine, sodium cromoglycate, and ipratropium bromide were $38 \cdot 1 \%(5 \cdot 0), 34 \cdot 5 \%(6 \cdot 1), 11 \cdot 3 \%(3 \cdot 7)$, and $19 \cdot 3 \%(7 \cdot 4)$ respectively. Similarly, the mean maximal falls in MMFR after saline, lignocaine, sodium cromoglycate, and ipratropium bromide were $54 \cdot 4 \%(5 \cdot 2), 52 \cdot 9 \%(7 \cdot 7), 23 \cdot 6 \%(6 \cdot 6)$, and $32 \cdot 1 \%(10 \cdot 5)$ respectively. The inhibitory effects of sodium cromoglycate and ipratropium bromide were significant whereas lignocaine failed to produce an effect. These results suggest that mediator release is an important factor in exercise-induced asthma and that in some patients the effects of the mediators may be on the postsynaptic muscarinic receptors. Local anaesthesia of sensory vagal receptors, on the other hand, does not prevent exercise asthma and these receptors do not appear to have any important role in exercise-induced bronchoconstriction.

The exact mechanism of exercise-induced asthma remains unclear; stimulation of a vagal reflex and the release of mast cell mediators in response to exercise have both been postulated. I 2 Recent studies have related exercise asthma to hyperventilation and subsequent airway heat loss but have failed to clarify whether the respiratory heat loss stimulates the irritant receptors in the airways or causes mast cell degranulation. ${ }^{3}$ Local anaesthesia of the upper airways with lignocaine has been shown to inhibit bronchoconstriction induced by inhalation of cold air and by exercise in patients with asthma. ${ }^{+5}$ Sodium cromoglycate, which suppresses the release of mast cell mediators in vitro, is effective in preventing exercise-induced asthma. ${ }^{6} 7$ More recently sodium cromoglycate has been shown to attenuate bronchoconstriction induced by cold air, methacholine, and histamine in asthmatic patients. ${ }^{x-10}$ It has been proposed that this additional effect of sodium cromoglycate may be mediated either directly on the bronchial smooth muscle or through an action on the

Address for reprint requests: Dr KR Patel, Western Infirmary, Glasgow G11 6NT. cholinergic receptors in the airways. In this study we have compared the effect of inhaled lignocaine. ipratropium bromide, and sodium cromoglycate in eight patients with extrinsic and reproducible exercise-induced asthma.

\section{Patients and methods}

Twelve patients with extrinsic and reproducible exercise-induced asthma were included in the trial. Four of these patients had to be excluded because they developed considerable and prolonged bronchoconstriction after inhalation of lignocaine $(4 \mathrm{~g} / \mathrm{l})$. The remaining eight patients, aged 17-49 years (mean $31 \cdot 2$, SEM $4 \cdot 0$ ) were studied. Sodium cromoglycate and bronchodilator drugs were discontinued for 24 hours before each test was carried out (patients taking oral or aerosol corticosteroids or antihistamines had been excluded from the study). All the patients were non-smokers and gave informed consent to be studied. Forced expiratory volume in one second $\left(\mathrm{FEV}_{1}\right)$ and maximum mid-expiratory flow rates (MMFR) were measured on a water- 
sealed spirometer (Godart Pulmotest). The best of three attempts was used for analysis and volumes were corrected to BTPS. Predicted normal values were taken from Cotes ${ }^{11}$ and Bates et al. ${ }^{12}$ The exercise test consisted of steady-state running on an inclined treadmill for up to eight minutes. During the exercise the patients breathed through their mouths, their noses being occluded with a clip. The speed of the treadmill was adjusted so that the pulse rate at the end of exercise was 160 beats per minute. The four tests in each patient were completed within seven to ten days to avoid changes in bronchial hyperreactivity. The temperature on study days was 20 $22{ }^{\circ} \mathrm{C}$ and the relative humidity ranged from $20 \%$ to $40 \%$. The study was carried out in a random singleblind fashion with normal saline $(9 \mathrm{~g} / \mathrm{l})$, lignocaine hydrochloride $(40 \mathrm{~g} / \mathrm{l})$, sodium cromoglycate nebuliser solution $(10 \mathrm{~g} / \mathrm{l})$, and ipratropium bromide $(0 \cdot 1 \mathrm{~g} / \mathrm{l})$. The drugs were delivered through a Wright nebuliser at a flow rate of $9 \mathrm{l} / \mathrm{min}\left(18 \mathrm{lb} / \mathrm{in}^{2}, 124 \mathrm{k} \cdot \mathrm{Pa}\right)$.
All inhalations were carried out by tidal breathing through the mouth. The estimated doses of lignocaine, sodium cromoglycate, and nebulised ipratropium were $48 \mathrm{mg}, 12 \mathrm{mg}$, and $120 \mu \mathrm{g}$ respectively. Spirometry was repeated 30 minutes after inhalation and then at $2,5,10,15$, and 30 minutes after exercise. Five of the patients were given two minutes' inhalation of $10 \%$ of citric acid. Induction of five or more coughs was considered as a positive response. The concentration of citric acid was increased to $20 \%$ if there was no cough response. The effects were assessed 30 minutes after lignocaine or saline inhalations. Results of exercise tests were expressed as the maximum fall in FEV , and MMFR from the post-drug baseline and analysed with Student's paired $t$ test (for both absolute and percentage changes).

\section{Results}

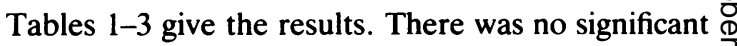

Table 1 Effect of saline, lignocaine, sodium cromoglycate, and ipratropium on exercise-induced change in FEV (litres) in eight patients

\begin{tabular}{|c|c|c|c|c|c|c|c|c|c|c|c|c|c|c|c|}
\hline \multirow[t]{2}{*}{$N o$} & \multirow[t]{2}{*}{ Age } & \multirow[t]{2}{*}{ Sex } & \multirow{2}{*}{$\begin{array}{l}\text { Predicted } \\
F E V_{I}\end{array}$} & \multicolumn{3}{|c|}{ Saline } & \multicolumn{3}{|c|}{ Lignocaine } & \multicolumn{3}{|c|}{ Sodium cromoglycate } & \multicolumn{3}{|c|}{ Ipratropium } \\
\hline & & & & \multicolumn{2}{|c|}{$\begin{array}{l}\text { Baseline } \\
A \quad B\end{array}$} & $\begin{array}{l}\text { Postexercise } \\
\text { change }\end{array}$ & \multicolumn{2}{|c|}{$\begin{array}{l}\text { Baseline } \\
A \quad B\end{array}$} & $\begin{array}{l}\text { Postexercise } \\
\text { change }\end{array}$ & \multicolumn{2}{|c|}{$\begin{array}{l}\text { Baseline } \\
A \quad B\end{array}$} & $\begin{array}{l}\text { Postexercise } \\
\text { change }\end{array}$ & \multicolumn{2}{|c|}{$\begin{array}{l}\text { Baseline } \\
A \quad B\end{array}$} & $\begin{array}{l}\text { Postexercise } \\
\text { change }\end{array}$ \\
\hline $\begin{array}{l}1 \\
2 \\
3 \\
4 \\
5 \\
6 \\
7 \\
8\end{array}$ & $\begin{array}{l}36 \\
24 \\
32 \\
49 \\
17 \\
44 \\
25 \\
22\end{array}$ & $\begin{array}{l}\mathbf{F} \\
\mathbf{M} \\
\mathbf{M} \\
\mathbf{M} \\
\mathbf{M} \\
\mathbf{M} \\
\mathbf{F} \\
\mathbf{F}\end{array}$ & $\begin{array}{l}2 \cdot 58 \\
3 \cdot 98 \\
3 \cdot 82 \\
3 \cdot 30 \\
4 \cdot 00 \\
3 \cdot 83 \\
3 \cdot 02 \\
2 \cdot 93\end{array}$ & $\begin{array}{l}2 \cdot 56 \\
4 \cdot 10 \\
2 \cdot 91 \\
2 \cdot 71 \\
3 \cdot 85 \\
3 \cdot 45 \\
2 \cdot 51 \\
3 \cdot 08\end{array}$ & $\begin{array}{l}2 \cdot 61 \\
4 \cdot 08 \\
2 \cdot 98 \\
2 \cdot 71 \\
3 \cdot 45 \\
3 \cdot 41 \\
2.52 \\
3.01\end{array}$ & $\begin{array}{l}-0.70 \\
-1.54 \\
-0.67 \\
-0.66 \\
-2.11 \\
-1.13 \\
-1.32 \\
-1.41\end{array}$ & $\begin{array}{l}2 \cdot 44 \\
3 \cdot 85 \\
2 \cdot 84 \\
2 \cdot 68 \\
3 \cdot 28 \\
3 \cdot 18 \\
3 \cdot 25 \\
3 \cdot 25\end{array}$ & $\begin{array}{l}2 \cdot 34 \\
4 \cdot 08 \\
2 \cdot 74 \\
2 \cdot 68 \\
3 \cdot 65 \\
3 \cdot 05 \\
2.95 \\
3 \cdot 18\end{array}$ & $\begin{array}{l}-0.90 \\
-1.87 \\
-0.66 \\
-0.47 \\
-1.84 \\
-0.65 \\
-1.85 \\
-0.50\end{array}$ & $\begin{array}{l}2.31 \\
4.02 \\
3.08 \\
2.58 \\
3.62 \\
3.18 \\
2.78 \\
3.01\end{array}$ & $\begin{array}{l}2 \cdot 18 \\
4 \cdot 12 \\
3 \cdot 01 \\
2 \cdot 60 \\
3 \cdot 92 \\
3 \cdot 28 \\
2 \cdot 71 \\
3 \cdot 08\end{array}$ & $\begin{array}{l}-0.16 \\
-1.21 \\
-0.13 \\
+0.11 \\
-0.27 \\
-0.67 \\
-0.57 \\
-0.10\end{array}$ & $\begin{array}{l}2 \cdot 44 \\
3 \cdot 82 \\
2 \cdot 71 \\
2 \cdot 11 \\
3 \cdot 52 \\
3 \cdot 15 \\
2 \cdot 51 \\
3 \cdot 15\end{array}$ & $\begin{array}{l}2 \cdot 78 \\
4 \cdot 27 \\
3 \cdot 48 \\
2 \cdot 71 \\
3 \cdot 62 \\
3 \cdot 85 \\
2 \cdot 78 \\
3 \cdot 75\end{array}$ & $\begin{array}{l}-0.07 \\
-1.34 \\
-0.30 \\
-0.34 \\
-1.08 \\
+0.03 \\
-1.91 \\
-0.27\end{array}$ \\
\hline \multicolumn{2}{|c|}{ Mean } & $\begin{array}{r}31 \cdot 2 \\
4 \cdot 0\end{array}$ & $\begin{array}{l}3 \cdot 43 \\
0 \cdot 19\end{array}$ & $\begin{array}{l}3 \cdot 15 \\
0 \cdot 21\end{array}$ & $\begin{array}{l}3 \cdot 10 \\
0 \cdot 19\end{array}$ & $\begin{array}{r}-1 \cdot 19 \\
0.18\end{array}$ & $\begin{array}{l}3 \cdot 0 \\
0 \cdot 15\end{array}$ & $\begin{array}{l}3.08 \\
0.20\end{array}$ & $\begin{array}{r}-1.09 \\
0.23\end{array}$ & $\begin{array}{l}3.08 \\
0.20\end{array}$ & $\begin{array}{l}3 \cdot 11 \\
0 \cdot 23\end{array}$ & $\begin{array}{r}-0.36 \\
0.15\end{array}$ & $\begin{array}{l}2 \cdot 93 \\
0 \cdot 21\end{array}$ & $\begin{array}{l}3.41 \\
0.21\end{array}$ & $\begin{array}{r}-0.66 \\
0.24\end{array}$ \\
\hline
\end{tabular}

A - before drug; B - after drug.

Table 2 Effect of saline, lignocaine, sodium cromoglycate, and ipratropium on exercise-induced change in maximal mid-expiratory flow rate $(M M F R)\left(l s^{-1}\right)$ in eight patients

\begin{tabular}{|c|c|c|c|c|c|c|c|c|c|c|c|c|c|}
\hline \multirow[t]{2}{*}{ No } & \multirow{2}{*}{$\begin{array}{l}\text { Predicted } \\
\text { MMFR }\end{array}$} & \multicolumn{3}{|c|}{ Saline } & \multicolumn{3}{|c|}{ Lignocaine } & \multicolumn{3}{|c|}{ Sodium cromoglycate } & \multicolumn{3}{|c|}{ Ipratropium } \\
\hline & & $\begin{array}{l}\text { Basel } \\
A\end{array}$ & & $\begin{array}{l}\text { Postexercise } \\
\text { change }\end{array}$ & $\begin{array}{l}\text { Basel } \\
A\end{array}$ & & $\begin{array}{l}\text { Postexercise } \\
\text { change }\end{array}$ & $\begin{array}{l}\text { Baseli } \\
A\end{array}$ & $\begin{array}{r}\text { line } \\
B\end{array}$ & $\begin{array}{l}\text { Postexercise } \\
\text { change }\end{array}$ & $\begin{array}{l}\text { Basel } \\
A\end{array}$ & ine & $\begin{array}{l}\text { Postexercise } \\
\text { change }\end{array}$ \\
\hline $\begin{array}{l}1 \\
2 \\
3 \\
4 \\
5 \\
6 \\
7 \\
8\end{array}$ & $\begin{array}{l}3 \cdot 26 \\
4 \cdot 40 \\
4 \cdot 24 \\
3 \cdot 47 \\
4 \cdot 61 \\
3 \cdot 92 \\
3 \cdot 80 \\
3 \cdot 50\end{array}$ & $\begin{array}{l}2.55 \\
7.36 \\
2.29 \\
1.56 \\
3.14 \\
1.96 \\
1.90 \\
2.73\end{array}$ & $\begin{array}{l}2.74 \\
6.41 \\
2.32 \\
1.57 \\
2.50 \\
1.91 \\
1.90 \\
2.58\end{array}$ & $\begin{array}{l}-1.37 \\
-4.32 \\
-0.81 \\
-0.51 \\
-1.77 \\
-0.99 \\
-1.26 \\
-1.59\end{array}$ & $\begin{array}{l}2 \cdot 32 \\
6 \cdot 31 \\
2 \cdot 08 \\
1 \cdot 71 \\
2 \cdot 18 \\
1 \cdot 63 \\
3 \cdot 82 \\
3 \cdot 11\end{array}$ & $\begin{array}{l}2.40 \\
6.44 \\
1.94 \\
1.70 \\
3.06 \\
1.72 \\
2.52 \\
3.24\end{array}$ & $\begin{array}{l}-1.49 \\
-4.62 \\
-0.69 \\
-0.38 \\
-2.31 \\
-0.65 \\
-2.00 \\
-1.13\end{array}$ & $\begin{array}{l}2.03 \\
6 \cdot 31 \\
2.68 \\
1.54 \\
2.79 \\
1.64 \\
2 \cdot 19 \\
2 \cdot 83\end{array}$ & $\begin{array}{l}1.75 \\
6.90 \\
2.47 \\
1.77 \\
3.76 \\
1.80 \\
2.17 \\
2.50\end{array}$ & $\begin{array}{l}-0.19 \\
-4.07 \\
-0.29 \\
-0.16 \\
-0.97 \\
-0.62 \\
-0.76 \\
-0.08\end{array}$ & $\begin{array}{l}2.36 \\
4.69 \\
1.92 \\
1.20 \\
2.66 \\
1.58 \\
2.16 \\
3.54\end{array}$ & $\begin{array}{l}3 \cdot 25 \\
8 \cdot 52 \\
2 \cdot 90 \\
1 \cdot 67 \\
2 \cdot 53 \\
2 \cdot 35 \\
2 \cdot 28 \\
5 \cdot 27\end{array}$ & $\begin{array}{l}-0.13 \\
-6.34 \\
-0.43 \\
-0.34 \\
-0.95 \\
-0.06 \\
-1.80 \\
-1.27\end{array}$ \\
\hline $\begin{array}{l}\text { Mean } \\
\text { SEM }\end{array}$ & $\begin{array}{l}3 \cdot 90 \\
0 \cdot 17\end{array}$ & $\begin{array}{l}2.94 \\
0.66\end{array}$ & $\begin{array}{l}2 \cdot 74 \\
0.54\end{array}$ & $\begin{array}{r}-1.58 \\
0.42\end{array}$ & $\begin{array}{l}2 \cdot 89 \\
0.55\end{array}$ & $\begin{array}{l}2.88 \\
0.55\end{array}$ & $\begin{array}{r}-1.53 \\
0.51\end{array}$ & $\begin{array}{l}2 \cdot 75 \\
0 \cdot 54\end{array}$ & $\begin{array}{l}2.89 \\
0.61\end{array}$ & $\begin{array}{r}-0.89 \\
0.47\end{array}$ & $\begin{array}{l}2 \cdot 51 \\
0.40\end{array}$ & $\begin{array}{l}3 \cdot 60 \\
0 \cdot 80\end{array}$ & $\begin{array}{r}-1.42 \\
0.76\end{array}$ \\
\hline
\end{tabular}

A - before drug; B - after drug 
Table 3 Effect of saline, lignocaine, sodium cromoglycate, and ipratropium on the mean exercise-induced change in FEV and maximal mid-expiratory flow rate (MMFR) in eight patients

\begin{tabular}{|c|c|c|}
\hline Drug & $\begin{array}{l}F E V_{1} \\
\text { Mean (士 SEM) change (\%) }\end{array}$ & $\begin{array}{l}\text { MMFR } \\
\text { Mean }( \pm S E M) \text { change }(\%)\end{array}$ \\
\hline $\begin{array}{l}\text { Saline } \\
\text { Lignocaine } \\
\text { Sodium cromoglycate } \\
\text { Ipratropium }\end{array}$ & $\begin{array}{l}38 \cdot 1(5 \cdot 1) \\
34 \cdot 5(6 \cdot 1) \\
11 \cdot 3(3 \cdot 7) \\
19 \cdot 3(7 \cdot 4)\end{array}$ & $\begin{array}{l}54.4(5 \cdot 2) \\
52.9(7 \cdot 7) \\
23.6(6 \cdot 6) \\
32 \cdot 1(10 \cdot 5)\end{array}$ \\
\hline $\begin{array}{l}\text { Saline } v \text { lignocaine } \\
\text { Saline } v \text { sodium cromoglycate } \\
\text { Saline } v \text { ipratropium } \\
\text { Lignocaine } v \text { sodium cromoglycate } \\
\text { Lignocaine } v \text { ipratropium } \\
\text { Sodium cromoglycate } v \text { ipratropium }\end{array}$ & $\begin{array}{l}p \\
\text { NS } \\
<0.01 \\
<0.02 \\
<0.01 \\
<0.01 \\
\text { NS }\end{array}$ & $\begin{array}{l}\text { NS } \\
<0.01 \\
<0.05 \\
<0.01 \\
<0.05 \\
\text { NS }\end{array}$ \\
\hline
\end{tabular}

difference between the mean baseline values of $\mathrm{FEV}_{1}$ and MMFR before inhalations of saline, lignocaine, sodium cromoglycate, and ipratropium on the four days of exercise testing. Saline, lignocaine, and sodium cromoglycate inhalations did not have a significant effect on the mean $\mathrm{FEV}_{1}$ or MMFR. Ipratropium caused bronchodilation with an increase in the mean $\mathrm{FEV}_{1}$, of $16.3 \%(\mathrm{p}<0.001)$ and mean MMFR of $43.4 \%(p<0.05)$.

After exercise the maximal percentage falls in $\mathrm{FEV}_{1}$ (means and SEM) after saline, lignocaine, sodium cromoglycate, and ipratropium were $38.1 \%$ $(5.0), 34.5 \%(6 \cdot 1), 11.3 \%(3.7)$, and $19.3 \%(7.4)$ respectively. Sodium cromoglycate $(p<0.01)$ and ipratropium $(p<0.02)$ both significantly inhibited the fall in $F E V_{1}$ whereas lignocaine failed to produce an effect. Similarly, the mean maximal percentage falls in MMFR after saline, lignocaine, sodium cromoglycate, and ipratropium were $54.4 \%$ (5.2), $52.9 \%(7.7)$, $23.6 \%(6 \cdot 6)$ and $32 \cdot 1 \%(10 \cdot 5)$. The inhibitory effects of sodium cromoglycate and ipratropium bromide were similar and no significant difference was found between the two drugs. When compared with lignocaine, the effects of sodium cromoglycate and ipratropium were significantly different $(\mathrm{p}<0.01)$. In five of our eight patients lignocaine suppressed coughing induced by citric acid at 30 minutes, suggesting that the local anaesthesia of the upper airways was effective when the patients were exercised. Sodium cromoglycate and ipratropium were both well tolerated by all subjects.

\section{Discussion}

Sodium cromoglycate and iptratropium bromide both significantly inhibited exercise-induced asthma as measured by the fall in FEV $\mathrm{V}_{1}$ and MMFR, whereas local anaesthesia with lignocaine failed to produce an effect. Lignocaine is reported to cause bronchoconstriction in asthmatic patients ${ }^{13}$ and four of the original 12 patients entering this study had to be excluded because of this. Although no significant improvement was noted in FEV $\mathrm{F}_{1}$ and MMFR after inhalation of lignocaine, all our subjects stated that the sensation of postexercise bronchoconstriction was lessened. The upper airways anaesthesia was effective in our patients as assessed by suppression of coughing induced by citric acid. The dose of lignocaine used in this trial was similar to that used by Enright and his colleagues, ${ }^{5}$ but we were unable to substantiate their observations.

Recent work has suggested that exercise-induced asthma is related to hyperventilation and subsequent airway heat loss, but it remains unclear whether this is due primarily to stimulation of irritant vagal receptors or to a direct effect on mast cell degranulation. ${ }^{2}$ While isocapnic hyperventilation does not cause a rise in blood histamine concentrations in asthmatic patients, ${ }^{14} 15$ some workers have shown a rise in histamine after exercise, particularly in patients with asthma. ${ }^{15-17}$ The failure of local anaesthesia to modify bronchoconstriction induced by histamine and prostaglandin $F_{2 \alpha}{ }^{18}$ and also to prevent exerciseinduced asthma suggests that the mechanism of postexercise bronchoconstriction is probably different from that of bronchoconstriction produced by hyperventilation and airway cooling. The beneficial effects of ipratropium bromide and sodium cromoglycate observed in exercise-induced asthma support previous observations. ${ }^{1219}$ The preventive effect of sodium cromoglycate was greater than that of ipratropium bromide, though the difference did not reach significance. The vagal mechanism apparently plays an important part only in patients whose main site of airflow obstruction is in the large airways. ${ }^{219}$ In contrast, sodium cromoglycate prevents exerciseinduced asthma irrespective of the site of airflow obstruction $^{19}$ and also attenuates the bronchoconstriction induced by cold air in asthmatic patients. ${ }^{8}$ Sodium cromoglycate, in addition to 
stabilising the mast cell membrane, may suppress the bronchial reactivity to the released mediators and this may explain why it is more effective in preventing exercise-induced asthma than is ipratropium bromide. The failure of local anaesthesia to prevent exercise-induced bronchoconstriction or to modify the effect of inhaled histamine and prostaglandin $\mathrm{F}_{2 \alpha}{ }^{18}$ suggests that the sensory irritant receptors in the airway do not have a significant role in exerciseinduced or chemically induced bronchoconstriction. Blockade of the muscarinic receptor, however, is known to modify both the exercise-induced asthma and non-specific bronchial reactivity. This would imply that in some patients the vagal reflex may be an important component of bronchoconstriction and that this effect is possibly mediated through the postsynaptic muscarinic receptors.

We thank Mrs Rita Jack for technical assistance.

\section{References}

1 Anonymous. Arms and bronchi. Lancet 1976;i:287-9.

2 McFadden ER, Ingram RH, Haynes RL, Wellman JJ. Predominant site of flow limitation and mechanism of post exertional asthma. J Appl Physiol 1977;42:746-52.

3 Zeballos RJ, Shturman-Ellestein R, McNally JR, Hirsch JE, Souhrada JF. The role of hyperventilation in exercise induced bronchoconstriction. Am Rev Respir Dis 1978;118:877-84.

+ Rodriguez-Martinez F, Marcia AU, Melius RB. The effect of environmental temperature on airway resistance in asthmatic child. Pediatr Res 1973;7: 627-32.

5 Enright PL, McNally JF, Souhrada JF. Effect of lidocaine on the ventilatory and airway responses to exercise in asthmatics. Am Rev Respir Dis 1980;122:823-8.

6 Orr TSC, Pollard MC, Gwilliam J, Cox JSG. Mode of action of disodium cromoglycate studies on immediate type hypersensitivity reaction using "double sensitisa- tion" with antigenically distinct rat reagins. Clin $\operatorname{Exp}$ Immunol 1970;7:745-57.

7 Davies SE. Effect of disodium cromoglycate on exercise- $\frac{\bar{O}}{\bar{S}}$ induced asthma. $\mathrm{Br}$ Med J 1968;iii:593-4.

8 Breslin FJ, McFadden ER, Ingram RH. The effect of $\stackrel{\mathbb{D}}{\Omega}$ cromolyn sodium on the airway response to hyperpnoea and cold air in asthma. Am Rev Respir Dis 1980;122:11-16.

${ }^{9}$ Woenne R, Kattan M, Levison $H$. Sodium cromoglycate- $\vec{\overrightarrow{ }}$ induced change in the dose-response curve of inhaled methacholine and histamine in asthmatic children. $A m)$
Rev Respir Dis 1979;119:927-32.

10 Woolcock AJ, Solome CM, Schoeffel RE. The effect of sodium cromoglycate on bronchial challenge with methacholine. In: Pepys J, Edwards AM, eds. The mast $\stackrel{\circ}{\circ}$ cell: its role in health and disease. Tunbridge Wells: Wै Pitman Medical, 1979:271-9.

11 Cotes JE. Lung Function. 3rd edn. Oxford: Blackwell, 1975:380.

12 Bates DV, Macklem PT, Christie RV. Respiratory function in disease. 2nd edn. Philadelphia: WB $\frac{0}{0}$ Saunders, 1971:93-4.

13 Miller WC, Awe R. Effect of nebulised lidocaine on reactive airways. Am Rev Respir Dis 1975;111:739-41. $\vec{\varphi}$

14 Deal EC, Wasserman SI, Soter NA, Ingram RH. Evaluation of role played by mediators of immediate hypersensitivity in exercise-induced asthma. J Clin Invest 1980;65:659-65.

15 Barnes PJ, Brown MJ. Venous plasma histamine in exercise and hyperventilation-induced asthma in man. 을 Clin Sci 1981;61:159-62.

16 Ferris L, Anderson SE, Temple DM. Histamine release $\overrightarrow{\vec{B}}$ in exercise-induced asthma. Br Med J 1978;1:1697.

17 Charles IJ, Hartley JPR, Seaton A, Taylor WH, Westwood A. Arterial histamine in exercise-induced asthma. Clin Sci 1979;56:8.

18 Thomson NC. The effect of different pharmacological agents on respiratory reflexes in normal and asthmatic subjects. In: Pepys J, Edwards AM, eds. The mast cell: $\underset{\square}{\times}$ its role in health and disease. Tunbridge Wells: Pitman Medical 1979:325-31.

19 Thomson NC, Patel KR, Kerr JW. Sodium cromoglycate $\delta$ and ipratropium bromide in exercise-induced asthma. Thorax 1978;33:694-7. 